\title{
Phagocytic Integrins: Activation and Signaling
}

\author{
Alvaro Torres-Gomez ${ }^{1,2 *}$, Carlos Cabañas ${ }^{1,2,3 *}$ and Esther M. Lafuente ${ }^{1,2 *}$ \\ ${ }^{1}$ Department of Immunology, Ophthalmology and Otorhinolaryngology, School of Medicine, Universidad Complutense de \\ Madrid, Madrid, Spain, ${ }^{2}$ Instituto de Investigación Sanitaria Hospital 12 de Octubre (i+12), Madrid, Spain, ${ }^{3}$ Severo Ochoa \\ Center for Molecular Biology (CSIC-UAM), Madrid, Spain
}

\section{OPEN ACCESS}

Edited by:

Nicole Thielens,

UMR5075 Institut de Biologie

Structurale (IBS), France

Reviewed by:

Thomas Vorup-Jensen,

Aarhus University, Denmark

Kaz Nagaosa,

Hirosaki University, Japan

*Correspondence:

Alvaro Torres-Gomez atorr01@ucm.es

Carlos Cabañas

ccabanas@cbm.uam.es

Esther M. Lafuente

melafuente@med.ucm.es

Specialty section: This article was submitted to

Molecular Innate Immunity, a section of the journal

Frontiers in Immunology

Received: 30 January 2020 Accepted: 31 March 2020

Published: 30 April 2020

Citation:

Torres-Gomez A, Cabañas $C$ and

Lafuente EM (2020) Phagocytic

Integrins: Activation and Signaling.

Front. Immunol. 11:738.

doi: 10.3389/fimmu.2020.00738
Phagocytic integrins are endowed with the ability to engulf and dispose of particles of different natures. Evolutionarily conserved from worms to humans, they are involved in pathogen elimination and apoptotic and tumoral cell clearance. Research in the field of integrin-mediated phagocytosis has shed light on the molecular events controlling integrin activation and their effector functions. However, there are still some aspects of the regulation of the phagocytic process that need to be clarified. Here, we have revised the molecular events controlling phagocytic integrin activation and the downstream signaling driving particle engulfment, and we have focused particularly on $\alpha_{M} \beta_{2} / C R 3, \alpha_{x} \beta_{2} / C R 4$, and a brief mention of $\alpha_{v} \beta_{5} / \alpha_{v} \beta_{3}$ integrins.

Keywords: phagocytosis, integrins, signaling, CR3, Mac-1, complement

\section{INTRODUCTION}

Phagocytosis entails the engulfment and disposal of particles in sequential steps, including particle recognition, cytoskeletal remodeling, membrane protrusion, particle engulfment, and phagolysosomal digestion $(1,2)$. The role of integrins in phagocytosis is evolutionarily conserved and can be observed in Caenorhabditis elegans INA-1/PAT-3, which is involved in clearance of apoptotic cells (3), and Drosophila $\alpha$ PS3/ $\beta v$, which has roles in microbial defense and apoptotic cell removal $(4,5)$ (Table 1). In mammals, the orthologues $\alpha_{V} \beta_{3} / \alpha_{V} \beta_{5}$ are expressed in professional and non-professional phagocytes (endothelial, epithelial, fibroblast, and neuronal and mesenchymal cells) with a role in phosphatidylserine-rich apoptotic/necrotic body clearance. Professional phagocytes in mammals express complement receptors $\alpha_{M} \beta_{2} / C R 3$ and $\alpha_{X} \beta_{2}$ CR4, which are involved in host defense and tissue homeostasis (45). Other integrins with reduced phagocytic capacity $\left(\alpha_{5} \beta_{1}, \alpha_{2} \beta_{1}, \alpha_{3} \beta_{1}\right.$, and $\left.\alpha_{6} \beta_{1}\right)$ are involved in phagocytosis of fibrillar or denatured extracellular matrix components (Table $\mathbf{1}$ ).

Integrins are characterized by requiring activation to be functional. This review has focused on the main events determining $\beta_{2}$ integrin activation and downstream signaling in relation to cytoskeletal remodeling and particle engulfment, and it makes a special mention of the main differences between other phagocytic integrins, especially those involved in apoptotic cell clearance.

\section{INTEGRIN STRUCTURE AND ACTIVATION}

Phagocytic integrins are heterodimeric ( $\alpha$ and $\beta$ subunit) receptors. Subunits are divided into ectodomains, a transmembrane helix, and short cytoplasmic tails. The $\alpha$-subunit ectodomains contain $\mathrm{Mg}^{2+}$-binding metal-ion-dependent adhesive sites (MIDAS) and Adjacent to MIDAS (AdMIDAS), which binds inhibitory $\mathrm{Ca}^{2+}$ or activating $\mathrm{Mn}^{2+}(46,47)$. Ligand binding can occur 
TABLE 1 | Major mammalian phagocytic integrins and their invertebrate orthologues.

\begin{tabular}{|c|c|c|c|c|}
\hline Integrin & $\alpha$ l domain & Co-receptors & Phagocytic targets & Expression \\
\hline$\alpha_{M} \beta_{2}$ & + & $\begin{array}{l}\text { - SR-A1/2 (6) } \\
\text { - Dectin1 (7) } \\
\text { - RAGE (8) }\end{array}$ & $\begin{array}{l}\text { - iC3b-opsonized particles (9) } \\
\text { - iC3b-opsonized particles (9) } \\
\text { - C3d-opsonized particles (10) } \\
\text { - Denatured proteins (11, 12) } \\
\text { - Bacteria (LPS, LBP) }(13,14) \\
\text { - Zymosan (15, 16) } \\
\text { - Myelin sheaths (17) } \\
\text { - Platelet factor 4 (PF4) (18) } \\
\text { - LL-37 (19) }\end{array}$ & Professional phagocytes \\
\hline$\alpha_{x} \beta_{2}$ & + & - & $\begin{array}{l}\text { - iC3b-opsonized particles (9) } \\
\text { - Osteopontin (20) } \\
\text { - Fibrillar } \alpha \text {-synuclein ( } \alpha \text { SN) (21) }\end{array}$ & Professional phagocytes \\
\hline$\alpha_{2} \beta_{1}$ & + & - & - Collagen fibrils (22-24) & Non-professional phagocytes \\
\hline$\alpha_{3} \beta_{1}$ & - & - CD36/SCARB3 (25) & - Laminin (26) & Non-professional phagocytes \\
\hline$\alpha \vee \beta_{3}$ & - & $\begin{array}{l}\text { - TIM4 (32) } \\
\text { - CD36/SCARB3 (33) } \\
\text { - MerTK }(34,35)\end{array}$ & $\begin{array}{l}\text { - MFG-E8 opsonized }(36,37) \\
\text { - Gas6 through co-receptor }(38) \\
\text { - ProS1 through co-receptor }(39,40) \\
\text { - TSP-1 (41) }\end{array}$ & $\begin{array}{l}\text { Professional and non-professional } \\
\text { phagocytes }\end{array}$ \\
\hline$\alpha_{v} \beta_{5}$ & - & & - Apoptotic or necrotic bodies $(42,43)$ & $\begin{array}{l}\text { Professional and non-professional } \\
\text { phagocytes }\end{array}$ \\
\hline$\alpha P S 3 / \beta v$ & - & - & $\begin{array}{l}\text { - Peptidoglycan }(4,44) \\
\text { - Apoptotic cells }(4,5)\end{array}$ & Drosophila phagocytes. \\
\hline INA-1/PAT-3 & $?$ & - & - Apoptotic cells (3) & C. elegans phagocytes \\
\hline
\end{tabular}

either at the $\alpha$ I-domain ( $\alpha$-subunit) in $\alpha_{X}, \alpha_{M}$, and $\alpha_{2}$ or at the $\alpha / \beta$-chain interface in integrins without the $\alpha$ I domain (Figure 1A, Table 1).

Integrins are tightly regulated by conformational changes, a hallmark of which is cytoplasmic tail separation (48). Integrin conformations are described according to the state of the headpiece (open/closed; $\mathrm{H}^{+} / \mathrm{H}^{-}$) and leg ectodomains (extended/bent; $\mathrm{E}^{+} / \mathrm{E}^{-}$) (49). Resting integrins remain in an inactive/"bent" $\left(\mathrm{E}^{-} \mathrm{H}^{-}\right)$conformation with the lowest free energy $\left(-4.0 \mathrm{kcal} / \mathrm{mol}\right.$ for $\left.\alpha_{5} \beta_{1}\right)$ with respect to fully activated integrins (50). $\mathrm{E}^{-} \mathrm{H}^{-}$is characterized by a closed ligand-binding site and clasped membrane proximal regions (51). In activated integrins $\left(\mathrm{E}^{+} \mathrm{H}^{+}\right)$, the hybrid domain ( $\beta$-subunit) swings away from the $\alpha$-chain, and the membrane proximal regions unclasp. This correlates with the rearrangement of the MIDAS and opening of the ligand binding site (51).

Structural and mutational studies have investigated models of integrin activation to explore whether integrin extension or leg separation occurs first. Mutations and deletions of the CDloop ( $\beta$-subunit terminal domain) have been proposed to keep integrins from extending and have shown no impact on $\alpha_{V} \beta_{3}$ and $\alpha_{\text {IIb }} \beta_{3}$ activation (52); there is little proof that mutations in this region affects $\beta_{2}$ integrins (53), strongly indicating that releasing these constraints is not enough to induce activation.

Structural studies (54) have demonstrated that $\alpha_{X} \beta_{2}$ follows the "switch-blade" model of activation, where leg separation occurs first, releasing constraints of the bent conformation and opening of the ligand-binding site resulting in an intermediate/low affinity conformation $\mathrm{E}^{+} \mathrm{H}^{-}$(55). The $\mathrm{E}^{+} \mathrm{H}^{-}$ conformation has a free energy between 1.6 and $0.5 \mathrm{kcal} / \mathrm{mol}$, meaning the high affinity conformation is thermodynamically favored $(50,56)$. Mutations in the EGF3 repeat of the $\beta_{2}$-subunit have also been shown to induce a high affinity conformation through destabilizing the thermodynamically favorable bent conformation and facilitating leg separation (57). It is noteworthy that an $\mathrm{E}^{-} \mathrm{H}^{+}$conformation has been described for $\alpha_{\mathrm{L}} \beta_{2}$ and $\alpha_{M} \beta_{2}$, allowing integrins to bind ICAM in cis, which may regulate neutrophil function (58); however, the specifics of how this activation takes place remain unknown.

Integrin activity is regulated by changes in affinity and aggregation, with the latter affecting receptor avidity. Cytoplasmic proteins bind to $\alpha$ - or $\beta$-subunits causing tail separation, stabilizing their high affinity conformation $(48,59)$. This can be triggered either through signaling from other receptors ("inside-out" signaling, Figure 1B), direct ligandbinding, or experimentally, using $\mathrm{Mn}^{2+}$ (“outside-in” signaling, Figure 1C), which triggers downstream signaling pathways (60).

\section{INSIDE-OUT SIGNALING}

\section{Rap1 as a Signaling Node}

Early studies in complement-dependent phagocytosis using mutants of small GTPases pointed to Rap1 as the main regulator of $\alpha_{M} \beta_{2}$ activity (61) and to it being required for $\beta_{1}$-mediated 
A

\section{Low affinity \\ (E-H')}

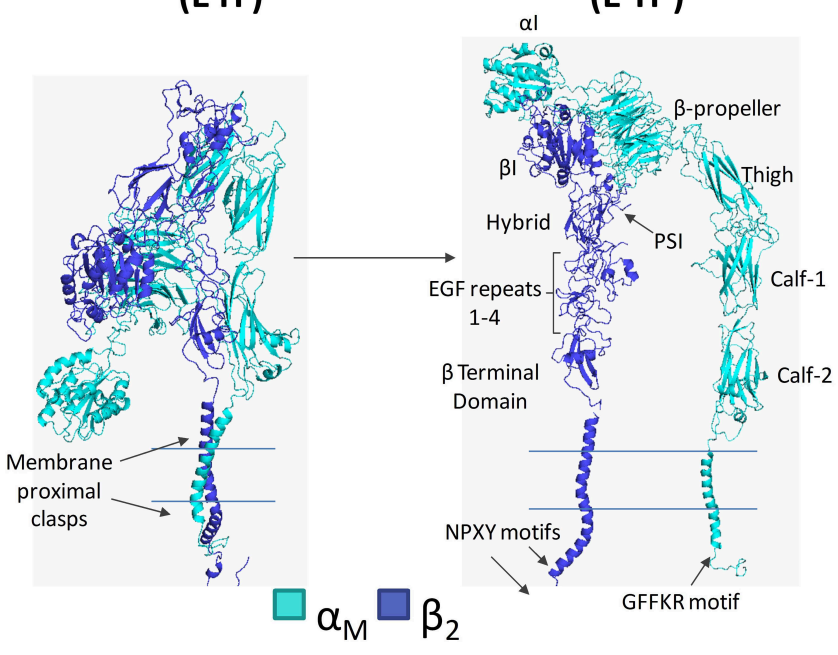

B Inside-Out

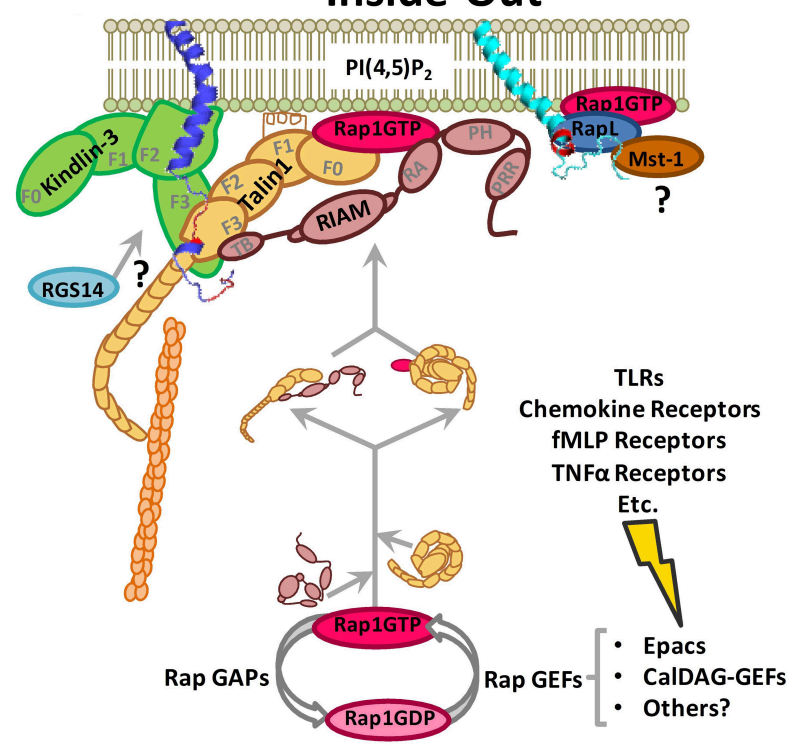

C

\section{Outside-In}

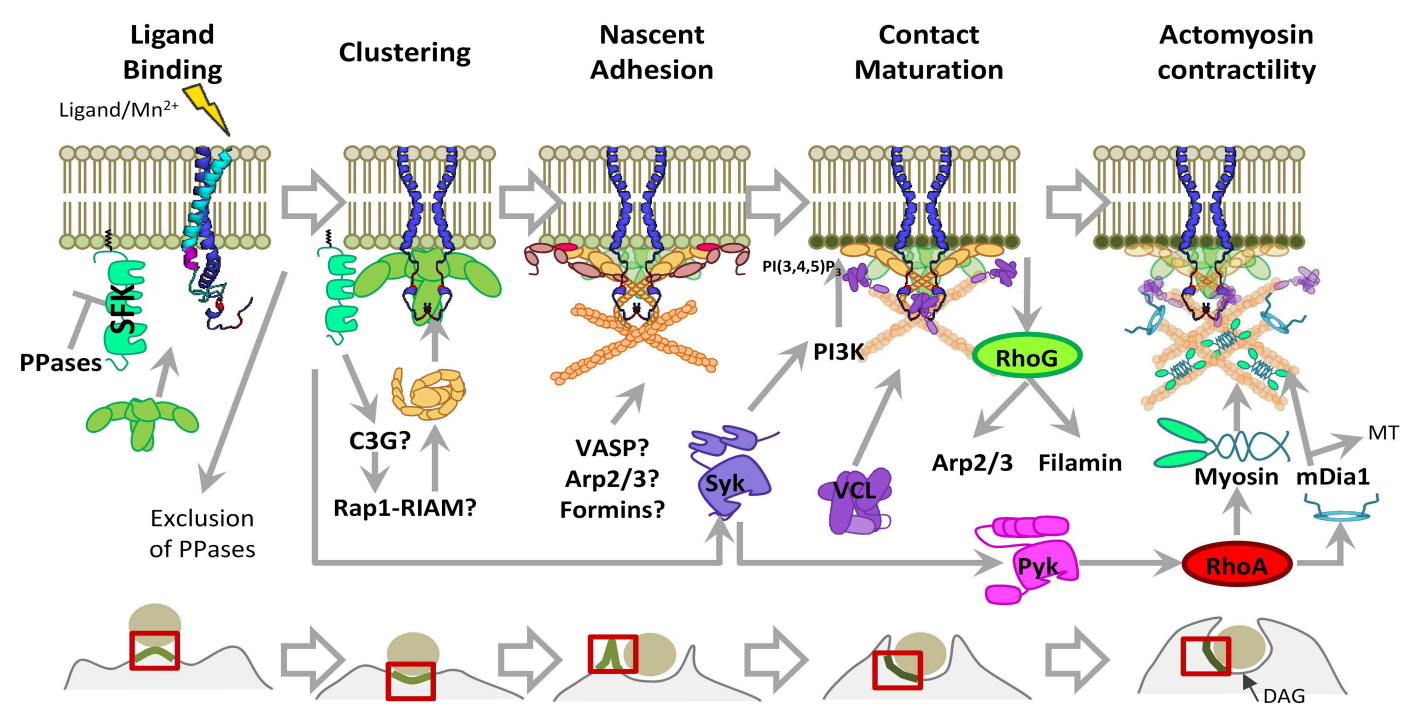

FIGURE 1 | Phagocytic integrin $\alpha_{M} \beta_{2}$ structure and activation pathways. (A) 3D structure model generated through homology modeling using Modeller 9.23. The following PBD entries served as templates: 1m8o, 2k9j, 2knc, and 3k6s (low-affinity/bent conformation), 1dpq, 2lkj, 2m3e, 2rn0, 2vdo, 3g9w, 3fcu, 5e6s, 6ckb, and 6 avu (high affinity conformation), and the sequences for $\alpha_{M}$ (NP_001139280.1) and $\beta_{2}$ (NP_000202.3). PSI: Plexin-Semaphorin-Integrin domain. (B) Inside-out pathway of integrin $\alpha_{M} \beta_{2}$ activation. Signals stemming from multiple receptors induce Rap1-GTP loading and RIAM-mediated recruitment of Talin1 to integrin tails, with possible contributions by other pathways. Protein-binding motifs in the integrin tails are shown in red (NPXY) and in purple (GFFKR). FERM domains are highlighted for Kindlin-3 and Talin1 (FO-F3). Highlighted RIAM domains are as follows; TB, Talin1 Binding domain; RA, Rap Association domain; PH, Pleckstrin Homology domain; PRR, Prolin Rich Region. (C) Outside-In pathway in the context of phagocytosis through $\alpha_{M} \beta_{2}$. Src Family Kinases remain inhibited by membrane-bound tyrosine phosphatases. Kindlin-3 mediated clustering facilitates Src Family Kinase activation, contact maturation and contractility necessary for phagocytic engulfment. PPases, Phosphatases; SFK, Src Family Kinases; MT, Microtubules. For simplicity, some proteins are shown as monomers. Question marks denote unsolved or hypothetical signaling steps.

phagocytosis (62). Rap1 acted as a node, connecting different signaling pathways (chemokines, fMLP, PAF, and TNF $\alpha$ ) for integrin activation (63). Rap1-GTP loading is induced by specific Guanine-Nucleotide Exchange Factors (GEFs), being Epac1 (dependent on cyclic AMP; cAMP) and CalDAG-GEFs (dependent on $\mathrm{Ca}^{2+} /$ Diacylglycerol; DAG), amongst the 
best characterized (Figure 1B). Epac1 expression was found to increase during monocyte-macrophage differentiation, correlating with the acquisition of immunoregulatory functions (64), and in neutrophilic HL-60 cells, pharmacological activation of Epac1 increased Rap1-GTP and complement-dependent phagocytosis (65). RasGRP3/CalDAG-GEFIII exhibited similar effects, promoting Rap1 activation and phagocytosis (66). Mutations in CalDAG-GEF1 produced leukocyte adhesion deficiency syndrome (LADIII) with defective neutrophilendothelial adhesion (67), and mouse CalDAG-GEF1 ${ }^{-{ }^{-}}$ macrophages showed reduced integrin activation (68). Rap1 activation can be induced by Toll-like receptors (TLRs) (69); however, the signaling pathways remain poorly defined. In neutrophils, secreted myeloid-related proteins (MRPs) 8 and 14 bind to TLR4 causing Rap1 activation and $\beta_{2}$-dependent adhesion (70). In macrophages, low concentrations of TLR3/4/9 agonists induced RasGRP3-dependent Rap1 activation (71). Activation of $\alpha_{M} \beta_{2}$ by TLR2/TLR4 required Rac1-GTP loading, PI3K activity, and cytohesin- 1 binding to the $\beta_{2}$ subunit (72).The role of cytohesin-1 is controversial, as the use of cytohesin-1 siRNAs and inhibitors results in an increase in the $\alpha_{M} \beta_{2}$ affinity conformation (73).

\section{Talin1 and Kindlin-3}

Talin1 and Kindlin-3 are the best-characterized integrin activators. Both belong to the FERM family but interact with distinct NPXY motifs in the cytoplasmic tails of $\beta_{1}, \beta_{2}$, and $\beta_{3}$, and they thus contribute differently to activation (74). Although Talin-binding is required for efficient $\beta_{5}$ activation during adhesion, it is dispensable for phagocytosis (75). $\alpha_{V} \beta_{5}$ requires an unknown mediator that recognizes a YEMAS motif proximal to the NPXY. A candidate could be the FERM family FRMD5, as it promotes $\beta_{5}$-Kindlin-2 interaction and induces ROCK activation during adhesion (76), yet there is no information of its relevance in phagocytosis.

Talin1 contains an N-terminal globular head with a linear FERM domain and a C-terminal rod domain organized in 13 subdomains (R1-R13), which contains a dimerization domain, an integrin binding site, three F-actin binding sites, and several Vinculin and RIAM binding sites $(77,78)$. The FERM domain has four subdomains (F0-F1-F2-F3), where F3 contains the primary integrin-binding site (IBS) that interacts with the membrane-proximal NPXY motif conserved in $\beta$-integrin tails $(59,79,80)$. In resting leukocytes, Talin1 remains auto-inhibited due to an interaction between F2F3 and R9 subdomains, which mask the primary IBS (81). Several Talin1 activation mechanisms have been proposed. By binding to $\operatorname{PIP} 5 \mathrm{~K} \gamma$, Talin1 is recruited to the plasma membrane where the F2F3 domain binds to phosphatidylinositol-4,5-bisphosphate $\left(\mathrm{PI}(4,5) \mathrm{P}_{2}\right)$, disrupting the head-tail interaction and exposing the IBS $(82,83)$. Additionally, RIAM-Talin1 interaction was described as necessary for Talin1 activation and recruitment to integrin tails (Figure 1B) (84).

Hematopoietic cell-specific Kindlin-3 is mutated in LADIII, causing $\beta_{1} / \beta_{2} / \beta_{3}$ activation defects $(85,86)$ and preventing neutrophils adhesion to iC3b and ICAM-1 (87). Kindlin-3 binds to the membrane-distal NPKF sequence in the $\beta_{2}$ subunit tail without excluding Talin1 binding (Figure 1B) (87). Studies of their individual contributions to activation revealed that Kindlin3 is not sufficient to induce the high-affinity state of $\alpha_{L} \beta_{2}$, whereas Talin1 promotes full activation (88). Whether binding of Talin1 and Kindlin-3 is sequential or simultaneous and their exact contribution to integrin activation remains to be explored. The signaling events directing Kindlin-3 to integrins also remain elusive, as in $\mathrm{T}$ cells, Kindlin-3 localization at immune synapses depends on Rap1 and Mst-1/RapL signaling (89), whereas no such interaction has been described for phagocytic cells.

\section{RIAM-Talin1 Interaction}

RIAM (Rap1-Interacting Adaptor Molecule or APBB1IP) was identified as a Rap1 effector that promoted a $\beta_{2}$ and $\beta_{1}$ high affinity state, increasing T-cell adhesion and spreading (90). RIAM binds to Rap1-GTP through a central Ras-association domain (RA), to PI(4,5) $\mathrm{P}_{2}$ through a Pleckstrin-Homology (PH) domain and to VASP, Profilin, and PLC $\gamma 1$ via proline-rich regions (90-94). RIAM also interacts with Talin1 through its $\mathrm{N}$-terminus and Talin1 has several RIAM-binding sites located at F3, R2, R3, R8, and R11 subdomains (77). Binding of RIAM to Talin1 releases Talin1 from its autoinhibition (Figure 1B) (95).

The Rap1-RIAM-Talin1-Integrin pathway also operates in complement-dependent phagocytosis. Studies in Talin1-silenced THP-1 cells revealed that Rap1 and Talin1 regulated each other's localization at phagocytic cups (96). Reduced RIAM expression in human monocyte-derived macrophages (MDM), neutrophilic HL-60 cells, and THP-1 cells diminished levels of high affinity $\alpha_{M} \beta_{2}$ and reduced complement-dependent phagocytosis and Talin1 recruitment to phagocytic cups (65). Complementdependent phagocytosis, cell adhesion to ICAM, and ROS production were also impaired in mouse $\mathrm{RIAM}^{-/-}$macrophages and neutrophils (97). Additionally, RIAM deficiency in vivo had a profound effect on $\beta_{2}$ activity but a moderate effect on $\beta_{1}$ - or $\beta_{3}$-dependent functions (98).

Besides RIAM, Rap1 effectors RapL and RGS14 (Regulator of G-Protein Signalling-14) have been proposed to regulate $\alpha_{M} \beta_{2}$ activation by inside-out signaling (Figure 1B). The former is proposed to interact with $\alpha_{\mathrm{M}}$-subunit inducing integrin tail separation and integrin activation (99); however, RapL has only been shown to interact with a GFFKR motif in $\alpha_{L}$ cytoplasmic tail, and there is no direct evidence that it plays a role in $\alpha_{M} \beta_{2}$ activation (100). For RGS14, the integrin activation mechanism is unknown but seems to be dependent on Talin1-binding to $\beta_{2}$ (101).

Recently, a direct interaction between Rap1-GTP and Talin1 was described at Talin1 F0 and F1 subdomains (102-105). Synergistic interaction between this region and an F1 lipidinteracting helix facilitates relocation of Talin1 and its integrinactivating function (Figure 1B) $(105,106)$. This pathway could be relevant for fast cell responses, as disruption in mice impaired platelet aggregation, neutrophil adhesion, extravasation, and phagocytosis but had no effect on macrophage adhesion and migration (104). 


\section{OUTSIDE-IN SIGNALING}

Outside-in signaling during phagocytosis initiates upon ligand interaction, stabilizing the active conformation, separating integrin tails, allowing for the binding of actin cytoskeletal linkers (Talin1 and/or Kindlin-3), and reorganizing cytoskeletal constraints, as described in the picket-fence model (2). This generates the force needed to drive membrane extension and particle engulfment/internalization (Figure 1C). Regulators have been described in focal complex-like formations at the phagocytic cup (107).

\section{CLUSTERING AND TYROSINE KINASES}

One of the earliest events in outside-in signaling could be ligand-induced clustering, a process requiring Talin1 and/or Kindlin-3 (74, 108). Kindlin-3-induced clustering is reported to activate Src family kinases (SFKs) $(109,110)$ by the exclusion of tyrosine phosphatases such as CD45 (68). Size exclusion of these membrane-bound phosphatases with large extracellular domains seems to be a common feature of integrin-mediated close-contact immune processes, such as Dectin-1 and Fc $\gamma$ RIII phagocytosis and immune synapse formation $(68,111,112)$. This process does not exclude SFKs but favors their activation due to removing the inhibitory effect of these phosphatases $(109,110)$. However, there are as of yet only indirect evidences $(109,110)$ that phosphatases such as CD45 are excluded during integrin-mediated phagocytosis.

SFKs appear to be exclusively involved in "outside-in" signaling, as SFK-deficient cells produced reduced ROS after integrin clustering (113), whereas ICAM-1 adhesion and complement-dependent phagocytosis were normal in preactivated SFK-deficient cells $(114,115)$.

A requirement for SFK activation has been described for $\beta_{1}$, $\beta_{2}$, and $\beta_{3}$ integrins $(109,114,116)$. Hck, Fgr, and Lyn are the representative SFKs in myeloid cells. Hck co-localized with $\alpha_{M} \beta_{2}$ at phagocytic cups of complement-opsonized zymosan $(117,118)$, and the Hck knockout phenocopied the $\alpha_{\mathrm{M}}$ knockout (119). However, in U937 macrophage-like cells, Hck and Fgr siRNA, unlike Lyn, had no effect on particle internalization (120), and genetic restitution of Fgr-deficient cells inhibited adhesion, spreading, and Syk activation (121). In contrast, the $\mathrm{Hck}^{-/-}$ $\mathrm{Fgr}^{-/-} \mathrm{Lyn}^{-/-}$triple knockout showed no inhibition in CR3mediated phagocytosis (122), which may point to compensatory roles of other ubiquitously expressed SFKs. Despite the research into outside-in activation of SFKs, the exact mechanism and individual contribution of each SFK have yet to be dissected.

SFK activity precedes activation of tyrosine kinases Syk and FAK family member Pyk2. Syk is necessary for phagocytosis of iC3b-opsonized beads/zymosan and localizes at phagocytic cups $(107,123)$, whereas Pyk2 contributes to clearance of complement-opsonized bacteria (124). Clustering of $\beta_{2}$ integrins results in Syk activation (125), which in turn triggers Pyk2 signaling (126). Pharmacological inhibition of Syk and FAK kinases points to non-redundant functions during phagocytosis and to a possible sequential activation (107).

\section{PHOSPHOINOSITIDES COORDINATE GTPASES AND CYTOSKELETAL REARRANGEMENTS}

Phagocytosis requires sequential enrichment of phosphoinositides (PIPs) in the inner leaflet of the plasma membrane (127). PIP enrichment recruits GEFs for small GTPases, which are sequentially activated (128), and other components of integrin adhesion complexes.

$\mathrm{PI}(4,5) \mathrm{P}_{2}$ enrichment can be induced by lipid redistribution due to particle-induced plasma membrane deformation (129) and/or by SFK or Talin1-induced PIP5K $\gamma$ activity (83, 130, 131). PI(4,5) $\mathrm{P}_{2}$ enrichment strengthens Talin1 anchoring (81) and recruits different factors involved in F-actin dynamics, like the actin-depolymerizing-factor $\mathrm{ADF} /$ Cofilin, whose activity is inhibited by $\mathrm{PI}(4,5) \mathrm{P}_{2}$ (132), or the formin mDia $(133,134)$. Additionally, RIAM binds $\mathrm{PI}(4,5) \mathrm{P}_{2}$ and may recruit VASP and Profilin, which could also contribute to actin polymerization (90, 93) (Figure 1C).

$\mathrm{PI}(3,4) \mathrm{P}_{2}$ recruits and induces Vinculin activation through disrupting an auto-inhibitory interaction (135). This is dependent on Syk activity and, to a lesser extent, on FAK/Pyk2 and is upstream from ROCK activation (107). In focal complexes, RIAM contributes to Vinculin binding to Talin1, as RIAM-Talin1 interaction unmasks a Vinculin binding site in Talin1 (77). Afterwards, Vinculin binding to F-actin and $\alpha$-actinin favors filament bundling and force generation $(136,137)$.

Increased PI $(3,4,5) \mathrm{P}_{3}$ at CR3-phagocytic cups (138) depends on PI3K (139) and Syk (126), and both are activated downstream of Kindlin-induced clustering (140). $\mathrm{PI}(3,4,5) \mathrm{P}_{3}$ enrichment recruits Vav1/3, which are GEFs for the RhoA family GTPases (128). Complement-dependent phagocytosis requires Vav1 to activate RhoA $(61,141)$ but also RhoG with no participation from Cdc42 and Rac1 (142). However, expression of constitutively active Rac1 rescues the defective engulfment of Vav1-3 knockouts (143). This discrepancy could be explained by the overlapping roles of RhoG and Rac1 $(144,145)$ (Figure 1C).

In the final steps leading to engulfment, RhoA-GTP initiates the ROCK-MLCK-myosin signaling pathway and actomyosin contractility (146). RhoA is enriched at phagocytic cups, and its localization is modulated by motifs in $\beta_{2}$-integrin tails (141). Premature activation of RhoA is inhibited by RapGTP through ARAP3, a dual GAP for Rho and Arf GTPases, which is recruited by $\mathrm{PI}(3,4,5) \mathrm{P}_{3}$ and $\mathrm{PI}(3,5) \mathrm{P}_{2}$ (147). Finally, mDia contributes to phagosome closure $(107,133)$ and particle engulfment by connecting the actin cytoskeleton to microtubules (148) (Figure 1C).

\section{SIGNALING DURING PHAGOCYTOSIS OF APOPTOTIC CELLS}

During apoptotic cell phagocytosis by mammalian $\alpha_{V} \beta_{5} / \alpha_{V} \beta_{3}$, a p130Cas-CrkII-Dock180-Elmo module induces Rac1 activation, which is responsible for cytoskeletal remodeling and phagosome formation $(149,150)$. Other known signals include the 
activation of SFKs, as signals from the Mer-TK receptor recruit phosphorylated FAK to mammalian $\beta_{5}$ in a Src-dependent manner (151), and Syk and Pyk2 activation has been shown to occur for $\alpha_{V} \beta_{3}(152,153)$. There is also evidence that Rac-1 activation is dependent on RhoG and its GEF Trio $(154,155)$, whereas RhoA inhibits engulfment (156), and the role of Cdc42 remains unclear (157-159).

An orthologous pathway using the CED-2-CED-5-CED10 module has been described for C. elegans INA-1, which activates the Rac ortholog and requires activation of SRC-1(Src-ortholog) (3). Similarly in Drosophila, severed axon clearance requires Src42A and Shark-the Src and Syk orthologs, respectively $(160,161)$ - pointing to an evolutionarily conserved pathway operating in apoptotic cell removal.

\section{DISCUSSION AND FUTURE PERSPECTIVES}

There are still critical gaps in the knowledge of phagocytic integrin signaling, specifically concerning proximal events and their hierarchy. There are several proposed alternative Talin1-recruitment mechanisms, but their contributions and significance are yet to be established. Rap1-Talin1 interaction is evolutionarily conserved and might constitute a mechanism for short-term adhesions (105), whereas Rap1-RIAM-Talin1 contacts would have a faster recruitment of effector proteins. In this line, it is yet to be established if RIAM is required for outsidein signaling, formation, and recycling of the focal adhesion-like complexes distributed in phagocytic cups (107).

Different F-actin nucleators/elongators are described to participate in CR3-mediated phagocytosis; however, their localization, recruitment, and relative contributions are unknown. The regulation of small GTPases, which control actin dynamics, remains obscure; there is scarce evidence of
GEF and GAP spatiotemporal localization in phagocytic cups, and it is well established that GTPases negatively regulate each other, which also raises questions on signal termination and negative-feedback loops.

Many structural and signaling proteins required for phagocytic integrin function have potential post-translational modification-dependent functions, and, although there are several candidates, little work has been undertaken to establish Ser/Thr kinase and phosphatase recruitment and localization within the phagocytic cup.

Fine-grain elucidation of the molecular mechanisms involved in integrin-mediated phagocytosis will yield invaluable information on possible control points for phagocyte functions (antigenic capture, pathogen, tumor or apoptotic body elimination, etc.). Indeed, complementopsonized immune complexes and particles may be presented directly by subcapsular sinus macrophages to naïve $B$ cells or conveyed to dendritic cells for B-cell presentation. This process requires cooperation between antigen-presenting cell $\alpha_{M} \beta_{2} / \alpha_{X} \beta_{2}$ and B-cell CR1, CR2, and/or Fc receptors (162165). Manipulation of this pathway may inform new vaccine strategies (166).

\section{AUTHOR CONTRIBUTIONS}

AT-G and EL wrote the original draft. AT-G prepared the figures. Final writing and editing were performed by AT-G, CC, and EL.

\section{FUNDING}

This work has been supported by Ministerio Español de Economía y Competitividad (MINECO) grants: SAF2016-77096$\mathrm{R}$ (EL and CC). AT-G was supported by an FPU predoctoral fellowship from MINECO.

\section{REFERENCES}

1. Rosales C, Uribe-Querol E. Phagocytosis: a fundamental process in immunity. BioMed Res Int. (2017) 2017:9042851. doi: 10.1155/2017/9042851

2. Niedergang F, Grinstein S. How to build a phagosome: new concepts for an old process. Curr Opin Cell Biol. (2018) 50:57-63. doi: 10.1016/j.ceb.2018.01.009

3. Hsu TY, Wu YC. Engulfment of apoptotic cells in C. elegans is mediated by integrin alpha/SRC signaling. Curr Biol. (2010) 20:47786. doi: 10.1016/j.cub.2010.01.062

4. Nonaka S, Nagaosa K, Mori T, Shiratsuchi A, Nakanishi Y. Integrin alphaPS3/betanu-mediated phagocytosis of apoptotic cells and bacteria in Drosophila. J Biol Chem. (2013) 288:1037480. doi: 10.1074/jbc.M113.451427

5. Nagaosa K, Okada R, Nonaka S, Takeuchi K, Fujita Y, Miyasaka T, et al. Integrin betanu-mediated phagocytosis of apoptotic cells in Drosophila embryos. J Biol Chem. (2011) 286:25770-7. doi: 10.1074/jbc.M110.204503

6. Reichert F, Rotshenker S. Complement-receptor-3 and scavengerreceptor-AI/II mediated myelin phagocytosis in microglia and macrophages. Neurobiol Dis. (2003) 12:65-72. doi: 10.1016/S0969-9961(02)0 0008-6

7. Li X, Utomo A, Cullere X, Choi MM, Milner Jr DA, Venkatesh D, et al. The $\beta$ glucan receptor Dectin-1 activates the integrin Mac-1 in neutrophils via Vav

protein signaling to promote Candida albicans clearance. Cell Host Microbe. (2011) 10:603-15. doi: 10.1016/j.chom.2011.10.009

8. Rojas A, Delgado-López F, González I, Pérez-Castro R, Romero J, Rojas I. The receptor for advanced glycation end-products: a complex signaling scenario for a promiscuous receptor. Cell Signall. (2013) 25:60914. doi: 10.1016/j.cellsig.2012.11.022

9. Springer TA, Anderson DC. Leukocyte complement receptors and adhesion proteins in the inflammatory response: insights from an experiment of nature. Biochem Soc Symp. (1986) 51:47-57.

10. Gaither TA, Vargas I, Inada S, Frank MM. The complement fragment C3d facilitates phagocytosis by monocytes. Immunology. (1987) 62:405-11.

11. Davis GE. The Mac-1 and p150, $95 \beta 2$ integrins bind denatured proteins to mediate leukocyte cell-substrate adhesion. Exp Cell Res. (1992) 200:24252. doi: 10.1016/0014-4827(92)90170-D

12. Hespanhol MR, Mantovani B. Phagocytosis by macrophages mediated by receptors for denatured proteins - dependence on tyrosine protein kinases. Braz J Med Biol Res. (2002) 35:383-9. doi: 10.1590/S0100-879X2002000300015

13. Agramonte-Hevia J, González-Arenas A, Barrera D, VelascoVelázquez M. Gram-negative bacteria and phagocytic cell interaction mediated by complement receptor 3. FEMS Immunol Med Microbiol. (2002) 34:255-66. doi: 10.1016/S0928-8244(02)0 0408-X 
14. Jones HE, Strid J, Osman M, Uronen-Hansson H, Dixon G, Klein N, et al. The role of beta 2 integrins and lipopolysaccharide-binding protein in the phagocytosis of dead Neisseria meningitidis. Cell Microbiol. (2008) 10:1634-45. doi: 10.1111/j.1462-5822.2008.01154.x

15. van Bruggen R, Drewniak A, Jansen M, van Houdt M, Roos D, Chapel $\mathrm{H}$, et al. Complement receptor 3, not Dectin-1, is the major receptor on human neutrophils for beta-glucan-bearing particles. Mol Immunol. (2009) 47:575-81. doi: 10.1016/j.molimm.2009.09.018

16. Le Cabec V, Cols C, Maridonneau-Parini I. Nonopsonic phagocytosis of zymosan and Mycobacterium kansasii by CR3 (CD11b/CD18) involves distinct molecular determinants and is or is not coupled with NADPH oxidase activation. Infect Immun. (2000) 68:4736-45. doi: 10.1128/IAI.68.8.4736-4745.2000

17. Reichert F, Slobodov U, Makranz C, Rotshenker S. Modulation (inhibition and augmentation) of complement receptor-3-mediated myelin phagocytosis. Neurobiol Dis. (2001) 8:504-12. doi: 10.1006/nbdi.2001.0383

18. Lishko VK, Yakubenko VP, Ugarova TP, Podolnikova NP. Leukocyte integrin Mac-1 (CD11b/CD18, alphaMbeta2, CR3) acts as a functional receptor for platelet factor 4. J Biol Chem. (2018) 293:6869-82. doi: 10.1074/jbc.RA117.000515

19. Zhang X, Bajic G, Andersen GR, Christiansen SH, Vorup-Jensen T. The cationic peptide LL-37 binds Mac-1 (CD11b/CD18) with a low dissociation rate and promotes phagocytosis. Biochim Biophys Acta. (2016) 1864:4718. doi: 10.1016/j.bbapap.2016.02.013

20. Schack L, Stapulionis R, Christensen B, Kofod-Olsen E, Skov Sorensen UB, Vorup-Jensen T, et al. Osteopontin enhances phagocytosis through a novel osteopontin receptor, the alphaXbeta2 integrin. J Immunol. (2009) 182:6943-50. doi: 10.4049/jimmunol.0900065

21. Juul-Madsen K, Qvist P, Bendtsen KL, Langkilde AE, Vestergaard B, Howard $\mathrm{KA}$, et al. Size-selective phagocytic clearance of fibrillar alpha-synuclein through conformational activation of complement receptor 4. J Immunol. (2020) 204:1345-61. doi: 10.4049/jimmunol.1900494

22. Lee W, Sodek J, McCulloch CA. Role of integrins in regulation of collagen phagocytosis by human fibroblasts. J Cell Physiol. (1996) 168:695704. doi: 10.1002/(SICI)1097-4652(199609)168:3<695::AID-JCP22>3.0. $\mathrm{CO} ; 2-\mathrm{X}$

23. Abraham LC, Dice JF, Lee K, Kaplan DL. Phagocytosis and remodeling of collagen matrices. Exp Cell Res. (2007) 313:104555. doi: 10.1016/j.yexcr.2006.12.019

24. Barth ND, Marwick JA, Vendrell M, Rossi AG, Dransfield I. The "phagocytic synapse" and clearance of apoptotic cells. Front Immunol. (2017) 8:1708. doi: 10.3389/fimmu.2017.01708

25. Thorne RF, Marshall JF, Shafren DR, Gibson PG, Hart IR, Burns GF. The integrins $\alpha 3 \beta 1$ and $\alpha 6 \beta 1$ physically and functionally associate with CD36 in human melanoma cells - requirement for the extracellular domain of CD36. J Biol Chem. (2000) 275:35264-75. doi: 10.1074/jbc.M003969200

26. Coopman PJ, Thomas DM, Gehlsen KR, Mueller SC. Integrin alpha 3 beta 1 participates in the phagocytosis of extracellular matrix molecules by human breast cancer cells. Mol Biol Cell. (1996) 7:1789-804. doi: 10.1091/mbc.7.11.1789

27. Zhao MW, Jin ML, He S, Spee C, Ryan SJ, Hinton DR. A distinct integrinmediated phagocytic pathway for extracellular matrix remodeling by RPE cells. Invest Ophthalmol Vis Sci. (1999) 40:2713-23.

28. Vernon-Wilson EF, Aurade F, Brown SB. CD31 promotes betal integrin-dependent engulfment of apoptotic Jurkat $\mathrm{T}$ lymphocytes opsonized for phagocytosis by fibronectin. I Leukoc Biol. (2006) 79:1260-7. doi: 10.1189/jlb.1005571

29. Blystone SD, Graham IL, Lindberg FP, Brown EJ. Integrin alpha v beta 3 differentially regulates adhesive and phagocytic functions of the fibronectin receptor alpha 5 beta 1. J Cell Biol. (1994) 127:112937. doi: $10.1083 /$ jcb.127.4.1129

30. Bamberger ME, Harris ME, McDonald DR, Husemann J, Landreth GE. A cell surface receptor complex for fibrillar beta-amyloid mediates microglial activation. J Neurosci. (2003) 23:2665-74. doi: 10.1523/JNEUROSCI.23-07-02665.2003

31. Koenigsknecht J, Landreth G. Microglial phagocytosis of fibrillar $\beta$-amyloid through a $\beta 1$ integrin-dependent mechanism. J Neurosci. (2004) 24:983846. doi: 10.1523/JNEUROSCI.2557-04.2004
32. Nishi C, Toda S, Segawa K, Nagata S. Tim4-and MerTK-mediated engulfment of apoptotic cells by mouse resident peritoneal macrophages. Mol Cell Biol. (2014) 34:1512-20. doi: 10.1128/MCB.01394-13

33. Fadok VA, Warner ML, Bratton DL, Henson PM. CD36 is required for phagocytosis of apoptotic cells by human macrophages that use either a phosphatidylserine receptor or the vitronectin receptor $(\alpha \mathrm{v} \beta 3)$. J Immunol. (1998) 161:6250-7.

34. Finnemann SC, Nandrot EF. MerTK activation during RPE phagocytosis in vivo requires $\alpha \mathrm{V} \beta 5$ integrin. Adv Exp Med Biol. (2006) 572:499-503. doi: 10.1007/0-387-32442-9_69.

35. Dransfield I, Zagórska A, Lew E, Michail K, Lemke G. Mer receptor tyrosine kinase mediates both tethering and phagocytosis of apoptotic cells. Cell Death Dis. (2015) 6:e1646. doi: 10.1038/cddis.2015.18

36. Akakura S, Singh S, Spataro M, Akakura R, Kim J-I, Albert ML, et al. The opsonin MFG-E8 is a ligand for the $\alpha \mathrm{v} \beta 5$ integrin and triggers DOCK180dependent Racl activation for the phagocytosis of apoptotic cells. Exp Cell Res. (2004) 292:403-16. doi: 10.1016/j.yexcr.2003.09.011

37. Hanayama R, Tanaka M, Miwa K, Shinohara A, Iwamatsu A, Nagata S. Identification of a factor that links apoptotic cells to phagocytes. Nature. (2002) 417:182. doi: 10.1038/417182a

38. Ishimoto $\mathrm{Y}$, Ohashi $\mathrm{K}$, Mizuno $\mathrm{K}$, Nakano $\mathrm{T}$. Promotion of the uptake of PS liposomes and apoptotic cells by a product of growth arrest-specific gene, gas6. J Biochem. (2000) 127:4117. doi: 10.1093/oxfordjournals.jbchem.a022622

39. Anderson HA, Maylock CA, Williams JA, Paweletz CP, Shu H, Shacter E. Serum-derived protein $S$ binds to phosphatidylserine and stimulates the phagocytosis of apoptotic cells. Nat Immunol. (2003) 4:87. doi: 10.1038/ni871

40. Savill J, Dransfield I, Hogg N, Haslett C. Vitronectin receptor-mediated phagocytosis of cells undergoing apoptosis. Nature. (1990) 343:1703. doi: $10.1038 / 343170 \mathrm{a} 0$

41. Moodley Y, Rigby P, Bundell C, Bunt S, Hayashi H, Misso N, et al. Macrophage recognition and phagocytosis of apoptotic fibroblasts is critically dependent on fibroblast-derived thrombospondin 1 and CD36. Am J Pathol. (2003) 162:771-9. doi: 10.1016/S0002-9440(10)63874-6

42. Greenberg ME, Sun M, Zhang R, Febbraio M, Silverstein R, Hazen SL. Oxidized phosphatidylserine-CD36 interactions play an essential role in macrophage-dependent phagocytosis of apoptotic cells. J Exp Med. (2006) 203:2613-625. doi: 10.1084/jem.20060370

43. Böttcher A, Gaipl US, Fürnrohr BG, Herrmann M, Girkontaite I, Kalden $\mathrm{JR}$, et al. Involvement of phosphatidylserine, $\alpha \mathrm{v} \beta 3, \mathrm{CD} 14, \mathrm{CD} 36$, and complement $\mathrm{Clq}$ in the phagocytosis of primary necrotic lymphocytes by macrophages. Arthr Rheumat. (2006) 54:927-38. doi: 10.1002/art.21660

44. Shiratsuchi A, Mori T, Sakurai K, Nagaosa K, Sekimizu K, Lee $\mathrm{BL}$, et al. Independent recognition of Staphylococcus aureus by two receptors for phagocytosis in Drosophila. J Biol Chem. (2012) 287:2166372. doi: 10.1074/jbc.M111.333807

45. Greenberg S, Grinstein S. Phagocytosis and innate immunity. Curr Opin Immunol. (2002) 14:136-45. doi: 10.1016/S0952-7915(01)00309-0

46. Valdramidou D, Humphries MJ, Mould AP. Distinct roles of $\beta 1$ metal ion-dependent adhesion site (MIDAS), adjacent to MIDAS (ADMIDAS), and ligand-associated metal-binding site (LIMBS) cation-binding sites in ligand recognition by integrin $\alpha 2 \beta 1$. J Biol Chem. (2008) 283:3270414. doi: 10.1074/jbc.M802066200

47. Zhang $\mathrm{K}$, Chen J. The regulation of integrin function by divalent cations. Cell Adhes Migr. (2012) 6:20-9. doi: 10.4161/cam.18702

48. Anthis NJ, Wegener KL, Ye F, Kim C, Goult BT, Lowe ED, et al. The structure of an integrin/talin complex reveals the basis of inside-out signal transduction. EMBO J. (2009) 28:3623-32. doi: 10.1038/emboj.20 09.287

49. Fan Z, Ley K. Leukocyte arrest: biomechanics and molecular mechanisms of $\beta 2$ integrin activation. Biorheology. (2015) 52:353-77. doi: 10.3233/BIR-15085

50. Li J, Springer TA. Energy landscape differences among integrins establish the framework for understanding activation. J Cell Biol. (2018) 217:397412. doi: $10.1083 /$ jcb. 201701169

51. Luo B-H, Carman CV, Springer TA. Structural basis of integrin regulation and signaling. Annu Rev Immunol. (2007) 25:619-47. doi: 10.1146/annurev.immunol.25.022106.141618 
52. Zhu J, Luo B-H, Barth P, Schonbrun J, Baker D, Springer TA. The structure of a receptor with two associating transmembrane domains on the cell surface: integrin aIIbß3. Mol Cell. (2009) 34:234-49. doi: 10.1016/j.molcel.2009.02.022

53. Gupta V, Gylling A, Alonso JL, Sugimori T, Ianakiev P, Xiong J$\mathrm{P}$, et al. The $\beta$-tail domain ( $\beta$ TD) regulates physiologic ligand binding to integrin CD11b/CD18. Blood. (2007) 109:351320. doi: 10.1182/blood-2005-11-056689

54. Xie C, Zhu J, Chen X, Mi L, Nishida N, Springer TA. Structure of an integrin with an alphaI domain complement receptor type 4. EMBO J. (2010) 29:666-79. doi: 10.1038/emboj.2009.367

55. Lefort CT, Hyun Y-M, Schultz JB, Law F-Y, Waugh RE, Knauf PA, et al. Outside-in signal transmission by conformational changes in integrin Mac-1. J Immunol. (2009) 183:6460-8. doi: 10.4049/jimmunol.0900983

56. Li J, Su Y, Xia W, Qin Y, Humphries MJ, Vestweber D, et al. Conformational equilibria and intrinsic affinities define integrin activation. EMBO J. (2017) 36:629-45. doi: 10.15252/embj.201695803

57. Zang Q, Springer TA. Amino acid residues in the PSI domain and cysteinerich repeats of the integrin $\beta 2$ subunit that restrain activation of the integrin $\alpha X \beta 2$. J Biol Chem. (2001) 276:6922-9. doi: 10.1074/jbc.M005868200

58. Fan Z, McArdle S, Marki A, Mikulski Z, Gutierrez E, Engelhardt B, et al. Neutrophil recruitment limited by high-affinity bent $\beta 2$ integrin binding ligand in cis. Nat Commun. (2016) 7:12658. doi: 10.1038/ncomms12658

59. Calderwood DA, Yan B, de Pereda JM, Alvarez BG, Fujioka Y, Liddington RC, et al. The phosphotyrosine binding-like domain of talin activates integrins. $J$ Biol Chem. (2002) 277:21749-58. doi: 10.1074/jbc.M111996200

60. Harburger DS, Calderwood DA. Integrin signalling at a glance. J Cell Sci. (2009) 122:159-63. doi: 10.1242/jcs.018093

61. Caron E, Hall A. Identification of two distinct mechanisms of phagocytosis controlled by different Rho GTPases. Science. (1998) 282:1717-21. doi: 10.1126/science.282.5394.1717

62. Arora PD, Conti MA, Ravid S, Sacks DB, Kapus A, Adelstein RS, et al. Rap1 activation in collagen phagocytosis is dependent on nonmuscle myosin II-A. Mol Biol Cell. (2008) 19:5032-46. doi: 10.1091/mbc.e08-04-0430

63. Caron E, Self AJ, Hall A. The GTPase Rap1 controls functional activation of macrophage integrin alphaMbeta2 by LPS and other inflammatory mediators. Curr Biol. (2000) 10:974-8. doi: 10.1016/S0960-9822(00)00641-2

64. Bryn T, Mahic M, Enserink JM, Schwede F, Aandahl EM, Taskén K. The cyclic AMP-Epac1-Rap1 pathway is dissociated from regulation of effector functions in monocytes but acquires immunoregulatory function in mature macrophages. J Immunol. (2006) 176:7361-70. doi: 10.4049/jimmunol.176.12.7361

65. Medrano-Fernandez I, Reyes R, Olazabal I, Rodriguez E, Sanchez-Madrid F, Boussiotis VA, et al. RIAM (Rap1-interacting adaptor molecule) regulates complement-dependent phagocytosis. Cell Mol Life Sci. (2013) 70:2395410. doi: 10.1007/s00018-013-1268-6

66. Botelho RJ, Harrison RE, Stone JC, Hancock JF, Philips MR, Jongstra-Bilen J, et al. Localized diacylglycerol-dependent stimulation of Ras and Rap1 during phagocytosis. J Biol Chem. (2009) 284:28522-32. doi: 10.1074/jbc.M109.009514

67. Pasvolsky R, Feigelson SW, Kilic SS, Simon AJ, Tal-Lapidot G, Grabovsky V, et al. A LAD-III syndrome is associated with defective expression of the Rap1 activator CalDAG-GEFI in lymphocytes, neutrophils, and platelets. $J$ Exp Med. (2007) 204:1571-82. doi: 10.1084/jem.20070058

68. Freeman SA, Goyette J, Furuya W, Woods EC, Bertozzi CR, Bergmeier $\mathrm{W}$, et al. Integrins form an expanding diffusional barrier that coordinates phagocytosis. Cell. (2016) 164:128-40. doi: 10.1016/j.cell.2015.11.048

69. Moon EY, Pyo S. Lipopolysaccharide stimulates Epac1-mediated Rap1/NFkappaB pathway in Raw 264.7 murine macrophages. Immunol Lett. (2007) 110:121-5. doi: 10.1016/j.imlet.2007.04.002

70. Pruenster M, Kurz AR, Chung KJ, Cao-Ehlker X, Bieber S, Nussbaum $\mathrm{CF}$, et al. Extracellular MRP8/14 is a regulator of beta2 integrindependent neutrophil slow rolling and adhesion. Nat Commun. (2015) 6:6915. doi: 10.1038/ncomms7915

71. Tang S, Chen T, Yu Z, Zhu X, Yang M, Xie B, et al. RasGRP3 limits Tolllike receptor-triggered inflammatory response in macrophages by activating Rap1 small GTPase. Nat Commun. (2014) 5:4657. doi: 10.1038/ncomms5657
72. Sendide K, Reiner NE, Lee JS, Bourgoin S, Talal A, Hmama Z. Crosstalk between CD14 and complement receptor 3 promotes phagocytosis of mycobacteria: regulation by phosphatidylinositol 3-kinase and cytohesin-1. J Immunol. (2005) 174:4210-9. doi: 10.4049/jimmunol.174.7.4210

73. El Azreq MA, Garceau V, Bourgoin SG. Cytohesin-1 regulates fMLFmediated activation and functions of the beta2 integrin Mac-1 in human neutrophils. J Leukoc Biol. (2011) 89:823-36. doi: 10.1189/jlb.0410222

74. Calderwood DA, Campbell ID, Critchley DR. Talins and kindlins: partners in integrin-mediated adhesion. Nat Rev Mol Cell Biol. (2013) 14:50317. doi: $10.1038 / \mathrm{nrm} 3624$

75. Singh S, D'mello V, en Henegouwen PB, Birge RB. A NPxY-independent $\beta 5$ integrin activation signal regulates phagocytosis of apoptotic cells. Biochem Biophys Res Commun. (2007) 364:540-8. doi: 10.1016/j.bbrc.2007.10.049

76. Hu J, Niu M, Li X, Lu D, Cui J, Xu W, et al. FERM domain-containing protein FRMD5 regulates cell motility via binding to integrin $\beta 5$ subunit and ROCK1. FEBS Lett. (2014) 588:4348-56. doi: 10.1016/j.febslet.2014.10.012

77. Goult BT, Zacharchenko T, Bate N, Tsang R, Hey F, Gingras AR, et al. RIAM and vinculin binding to talin are mutually exclusive and regulate adhesion assembly and turnover. J Biol Chem. (2013) 288:823849. doi: 10.1074/jbc.M112.438119

78. Hemmings L, Rees DJ, Ohanian V, Bolton SJ, Gilmore AP, Patel B, et al. Talin contains three actin-binding sites each of which is adjacent to a vinculin-binding site. J Cell Sci. (1996) 109(Pt 11):2715-26.

79. Wegener KL, Partridge AW, Han J, Pickford AR, Liddington RC, Ginsberg $\mathrm{MH}$, et al. Structural basis of integrin activation by talin. Cell. (2007) 128:171-82. doi: 10.1016/j.cell.2006.10.048

80. Garcia-Alvarez B, de Pereda JM, Calderwood DA, Ulmer TS, Critchley D, Campbell ID, et al. Structural determinants of integrin recognition by talin. Mol Cell. (2003) 11:49-58. doi: 10.1016/S1097-2765(02)00823-7

81. Dedden D, Schumacher S, Kelley CF, Zacharias M, Biertümpfel C, Fässler R, et al. The architecture of Talin 1 reveals an autoinhibition mechanism. Cell. (2019) 179:120-31 e13. doi: 10.1016/j.cell.2019.08.034

82. Ling K, Doughman RL, Firestone AJ, Bunce MW, Anderson RA. Type I gamma phosphatidylinositol phosphate kinase targets and regulates focal adhesions. Nature. (2002) 420:89-93. doi: 10.1038/nature01082

83. Di Paolo G, Pellegrini L, Letinic K, Cestra G, Zoncu R, Voronov S, et al. Recruitment and regulation of phosphatidylinositol phosphate kinase type 1 gamma by the FERM domain of talin. Nature. (2002) 420:859. doi: 10.1038/nature01147

84. Lee H-S, Lim CJ, Puzon-McLaughlin W, Shattil SJ, Ginsberg MH. RIAM activates integrins by linking talin to ras GTPase membrane-targeting sequences. J Biol Chem. (2009) 284:5119-27. doi: 10.1074/jbc.M807117200

85. Malinin NL, Zhang L, Choi J, Ciocea A, Razorenova O, Ma YQ, et al. A point mutation in KINDLIN3 ablates activation of three integrin subfamilies in humans. Nat Med. (2009) 15:313-8. doi: 10.1038/nm.1917

86. Svensson L, Howarth K, McDowall A, Patzak I, Evans R, Ussar $\mathrm{S}$, et al. Leukocyte adhesion deficiency-III is caused by mutations in KINDLIN3 affecting integrin activation. Nat Med. (2009) 15:30612. doi: $10.1038 / \mathrm{nm} .1931$

87. Moser M, Bauer M, Schmid S, Ruppert R, Schmidt S, Sixt M, et al. Kindlin3 is required for beta2 integrin-mediated leukocyte adhesion to endothelial cells. Nat Med. (2009) 15:300-5. doi: 10.1038/nm.1921

88. Lefort CT, Rossaint J, Moser M, Petrich BG, Zarbock A, Monkley SJ, et al. Distinct roles for talin-1 and kindlin-3 in LFA-1 extension and affinity regulation. Blood. (2012) 119:4275-82. doi: 10.1182/blood-2011-08-3 73118

89. Kondo N, Ueda Y, Kita T, Ozawa M, Tomiyama T, Yasuda K, et al. NDR1dependent regulation of kindlin-3 controls high-affinity LFA-1 binding and immune synapse organization. Mol Cell Biol. (2017) 37:e0042416. doi: 10.1128/MCB.00424-16

90. Lafuente EM, van Puijenbroek AA, Krause M, Carman CV, Freeman GJ, Berezovskaya A, et al. RIAM, an Ena/VASP and Profilin ligand, interacts with Rap1-GTP and mediates Rap1-induced adhesion. Dev Cell. (2004) 7:585-95. doi: 10.1016/j.devcel.2004.07.021

91. Colo GP, Lafuente EM, Teixido J. The MRL proteins: adapting cell adhesion, migration and growth. Eur J Cell Biol. (2012) 91:8618. doi: 10.1016/j.ejcb.2012.03.001 
92. Han J, Lim CJ, Watanabe N, Soriani A, Ratnikov B, Calderwood DA, et al. Reconstructing and deconstructing agonist-induced activation of integrin alphaIIbbeta3. Curr Biol. (2006) 16:1796-806. doi: 10.1016/j.cub.2006.08.035

93. Patsoukis N, Bardhan K, Weaver JD, Sari D, Torres-Gomez A, Li L, et al. The adaptor molecule RIAM integrates signaling events critical for integrinmediated control of immune function and cancer progression. Sci Signal. (2017) 10:eaam8298. doi: 10.1126/scisignal.aam8298

94. Patsoukis N, Lafuente EM, Meraner P, sub Kim J, Dombkowski D, Li L, et al. RIAM regulates the cytoskeletal distribution and activation of PLC- $\gamma 1$ in T cells. Sci Signal. (2009) 2:ra79. doi: 10.1126/scisignal.2000409

95. Yang J, Zhu L, Zhang H, Hirbawi J, Fukuda K, Dwivedi P, et al. Conformational activation of talin by RIAM triggers integrin-mediated cell adhesion. Nat Commun. (2014) 5:5880. doi: 10.1038/ncomms6880

96. Lim J, Dupuy AG, Critchley DR, Caron E. Rap1 controls activation of the alpha(M)beta(2) integrin in a talin-dependent manner. J Cell Biochem. (2010) 111:999-1009. doi: 10.1002/jcb.22788

97. Klapproth S, Sperandio M, Pinheiro EM, Prunster M, Soehnlein O, Gertler $\mathrm{FB}$, et al. Loss of the Rap1 effector RIAM results in leukocyte adhesion deficiency due to impaired beta 2 integrin function in mice. Blood. (2015) 126:2704-12. doi: 10.1182/blood-2015-05-647453

98. Stritt S, Wolf K, Lorenz V, Vogtle T, Gupta S, Bosl MR, et al. Rap1-GTP-interacting adaptor molecule (RIAM) is dispensable for platelet integrin activation and function in mice. Blood. (2015) 125:219-22. doi: 10.1182/blood-2014-08-597542

99. Han C, Jin J, Xu S, Liu H, Li N, Cao X. Integrin CD11b negatively regulates TLR-triggered inflammatory responses by activating Syk and promoting degradation of MyD88 and TRIF via Cbl-b. Nat Immunol. (2010) 11:73442. doi: 10.1038/ni.1908

100. Tohyama Y, Katagiri K, Pardi R, Lu C, Springer TA, Kinashi T. The critical cytoplasmic regions of the $\alpha \mathrm{L} / \beta 2$ integrin in Rapl-induced adhesion and migration. Mol Biol Cell. (2003) 14:2570-82. doi: 10.1091/mbc.e02-09-0615

101. Lim J, Thompson J, May RC, Hotchin NA, Caron E. Regulator of G-protein signalling-14 (RGS14) regulates the activation of alphaMbeta2 integrin during phagocytosis. PLoS ONE. (2013) 8:e69163. doi: 10.1371/journal.pone.0069163

102. Goult BT, Bouaouina M, Elliott PR, Bate N, Patel B, Gingras AR, et al. Structure of a double ubiquitin-like domain in the talin head: a role in integrin activation. EMBO J. (2010) 29:1069-80. doi: 10.1038/emboj.2010.4

103. Lagarrigue F, Gingras AR, Paul DS, Valadez AJ, Cuevas MN, Sun H, et al. Rap1 binding to the talin 1 F0 domain makes a minimal contribution to murine platelet GPIIb-IIIa activation. Blood Adv. (2018) 2:235868. doi: 10.1182/bloodadvances.2018020487

104. Bromberger T, Klapproth S, Rohwedder I, Zhu L, Mittmann L, Reichel CA, et al. Direct Rap1/Talin1 interaction regulates platelet and neutrophil integrin activity in mice. Blood. (2018) 132:2754-62. doi: 10.1182/blood-2018-04-846766

105. Bromberger T, Zhu L, Klapproth S, Qin J, Moser M. Rap1 and membrane lipids cooperatively recruit talin to trigger integrin activation. J Cell Sci. (2019) 132:jcs.235531. doi: 10.1242/jcs.235531

106. Gingras AR, Lagarrigue F, Cuevas MN, Valadez AJ, Zorovich M, McLaughlin $\mathrm{W}$, et al. Rap1 binding and a lipid-dependent helix in talin F1 domain promote integrin activation in tandem. J Cell Biol. (2019) 218:1799809. doi: $10.1083 /$ jcb. 201810061

107. Jaumouillé V, Cartagena-Rivera AX, Waterman CM. Coupling of $\beta$ 2 integrins to actin by a mechanosensitive molecular clutch drives complement receptor-mediated phagocytosis. Nat Cell Biol. (2019) 21:135769. doi: 10.1038/s41556-019-0414-2

108. Ye F, Petrich BG, Anekal P, Lefort CT, Kasirer-Friede A, Shattil SJ, et al. The mechanism of kindlin-mediated activation of integrin $\alpha$ IIb $\beta 3$. Curr Biol. (2013) 23:2288-95. doi: 10.1016/j.cub.2013.09.050

109. Arias-Salgado EG, Lizano S, Sarkar S, Brugge JS, Ginsberg MH, Shattil SJ. Src kinase activation by direct interaction with the integrin $\beta$ cytoplasmic domain. Proc Natl Acad Sci USA. (2003) 100:13298302. doi: 10.1073/pnas.2336149100

110. Xiao R, Xi X-D, Chen Z, Chen S-J, Meng G. Structural framework of $\mathrm{c}$-Src activation by integrin $\beta 3$. Blood. (2013) 121:700-6. doi: 10.1182/blood-2012-07-440644
111. Junghans V, Santos AM, Lui Y, Davis SJ, Jönsson P. Dimensions and interactions of large T-cell surface proteins. Front Immunol. (2018) 9:2215. doi: 10.3389/fimmu.2018.02215

112. Davis SJ, Van Der Merwe PA. The kinetic-segregation model: TCR triggering and beyond. Nat Immunol. (2006) 7:803-9. doi: 10.1038/ni1369

113. Lowell CA, Fumagalli L, Berton G. Deficiency of Src family kinases p59/61hck and p58c-fgr results in defective adhesion-dependent neutrophil functions. J Cell Biol. (1996) 133:895-910. doi: 10.1083/jcb.133.4.895

114. Giagulli C, Ottoboni L, Caveggion E, Rossi B, Lowell C, Constantin G, et al. The Src family kinases Hck and Fgr are dispensable for insideout, chemoattractant-induced signaling regulating $\beta 2$ integrin affinity and valency in neutrophils, but are required for $\beta 2$ integrin-mediated outsidein signaling involved in sustained adhesion. J Immunol. (2006) 177:60411. doi: 10.4049/jimmunol.177.1.604

115. Wetzel DM, Rhodes EL, Li S, McMahon-Pratt D, Koleske AJ. The Src kinases Hck, Fgr and Lyn activate Arg to facilitate IgG-mediated phagocytosis and Leishmania infection. J Cell Sci. (2016) 129:3130-43. doi: 10.1242/jcs.185595

116. Wu L, Bernard-Trifilo JA, Lim Y, Lim S-T, Mitra SK, Uryu S, et al. Distinct FAK-Src activation events promote $\alpha 5 \beta 1$ and $\alpha 4 \beta 1$ integrin-stimulated neuroblastoma cell motility. Oncogene. (2008) 27:143948. doi: 10.1038/sj.onc. 1210770

117. Astarie-Dequeker C, Carreno S, Cougoule C, Maridonneau-Parini I. The protein tyrosine kinase $\mathrm{Hck}$ is located on lysosomal vesicles that are physically and functionally distinct from CD63-positive lysosomes in human macrophages. J Cell Sci. (2002) 115:81-9.

118. Tang, R.-H., Law SA, Tan S-M. Selective recruitment of src family kinase Hck by leukocyte integrin $\alpha \mathrm{M} \beta 2$ but not $\alpha \mathrm{L} \beta 2$ or $\alpha \mathrm{X} \beta 2$. FEBS Lett. (2006) 580:4435-42. doi: 10.1016/j.febslet.2006.06.099

119. Hirahashi J, Mekala D, Van Ziffle J, Xiao L, Saffaripour S, Wagner DD, et al. Mac-1 signaling via Src-family and Syk kinases results in elastasedependent thrombohemorrhagic vasculopathy. Immunity. (2006) 25:27183. doi: 10.1016/j.immuni.2006.05.014

120. Adachi R, Suzuki K. Lyn, one of the Src-family tyrosine kinases expressed in phagocytes, plays an important role in $\beta 2$ integrin-signalling pathways in opsonized zymosan-activated macrophage-like U937 cells. Cell Biochem Funct. (2007) 25:323-33. doi: 10.1002/cbf.1393

121. Vines CM, Potter JW, Xu Y, Geahlen RL, Costello PS, Tybulewicz $\mathrm{VL}$, et al. Inhibition of $\beta 2$ integrin receptor and Syk kinase signaling in monocytes by the Src family kinase Fgr. Immunity. (2001) 15:50719. doi: 10.1016/S1074-7613(01)00221-7

122. Fitzer-Attas CJ, Lowry M, Crowley MT, Finn AJ, Meng F, DeFranco AL, et al. Fc $\gamma$ receptor-mediated phagocytosis in macrophages lacking the Src family tyrosine kinases Hck, Fgr, and Lyn. J Exp Med. (2000) 191:66982. doi: 10.1084/jem.191.4.669

123. Shi Y, Tohyama Y, Kadono T, He J, Miah SS, Hazama R, et al. Protein-tyrosine kinase Syk is required for pathogen engulfment in complement-mediated phagocytosis. Blood. (2006) 107:4554-62. doi: 10.1182/blood-2005-09-3616

124. Paone C, Rodrigues N, Ittner E, Santos C, Buntru A, Hauck CR. The tyrosine kinase Pyk2 contributes to complement-mediated phagocytosis in murine macrophages. J Innate Immun. (2016) 8:437-51. doi: 10.1159/000442944

125. Yan SR, Huang M, Berton G. Signaling by adhesion in human neutrophils: activation of the p72syk tyrosine kinase and formation of protein complexes containing p72syk and Src family kinases in neutrophils spreading over fibrinogen. J Immunol. (1997) 158:1902-10.

126. Mócsai A, Zhou M, Meng F, Tybulewicz VL, Lowell CA. Syk is required for integrin signaling in neutrophils. Immunity. (2002) 16:54758. doi: 10.1016/S1074-7613(02)00303-5

127. Bohdanowicz M, Cosío G, Backer JM, Grinstein S. Class I and class III phosphoinositide 3-kinases are required for actin polymerization that propels phagosomes. J Cell Biol. (2010) 191:999-1012. doi: 10.1083/jcb.201004005

128. Mao Y, Finnemann SC. Regulation of phagocytosis by Rho GTPases. Small GTPases. (2015) 6:89-99. doi: 10.4161/21541248.2014.989785

129. Mu L, Tu Z, Miao L, Ruan H, Kang N, Hei Y, et al. A phosphatidylinositol 4,5-bisphosphate redistribution-based sensing mechanism initiates a phagocytosis programing. Nat Commun. (2018) 9:4259. doi: 10.1038/s41467-018-06744-7 
130. Ling K, Doughman RL, Iyer VV, Firestone AJ, Bairstow SF, Mosher DF, et al. Tyrosine phosphorylation of type I $\gamma$ phosphatidylinositol phosphate kinase by Src regulates an integrin-talin switch. J Cell Biol. (2003) 163:133949. doi: $10.1083 /$ jcb. 200310067

131. Yago T, Zhang N, Zhao L, Abrams CS, McEver RP. Selectins and chemokines use shared and distinct signals to activate $\beta 2$ integrins in neutrophils. Blood Adv. (2018) 2:731-44. doi: 10.1182/bloodadvances.2017015602

132. Senju Y, Kalimeri M, Koskela EV, Somerharju P, Zhao H, Vattulainen I, et al. Mechanistic principles underlying regulation of the actin cytoskeleton by phosphoinositides. Proc Natl Acad Sci USA. (2017) 114:E897786. doi: 10.1073/pnas.1705032114

133. Colucci-Guyon E, Niedergang F, Wallar BJ, Peng J, Alberts AS, Chavrier P. A role for mammalian diaphanous-related formins in complement receptor (CR3)-mediated phagocytosis in macrophages. Curr Biol. (2005) 15:200712. doi: 10.1016/j.cub.2005.09.051

134. Lewkowicz E, Herit F, Le Clainche C, Bourdoncle P, Perez F, Niedergang F. The microtubule-binding protein CLIP-170 coordinates mDial and actin reorganization during CR3-mediated phagocytosis. J Cell Biol. (2008) 183:1287-98. doi: 10.1083/jcb.200807023

135. Bakolitsa C, de Pereda JM, Bagshaw CR, Critchley DR, Liddington RC. Crystal structure of the vinculin tail suggests a pathway for activation. Cell. (1999) 99:603-13. doi: 10.1016/S0092-8674(00)81549-4

136. Roca-Cusachs P, Del Rio A, Puklin-Faucher E, Gauthier NC, Biais N, Sheetz MP. Integrin-dependent force transmission to the extracellular matrix by $\alpha$-actinin triggers adhesion maturation. Proc Natl Acad Sci USA. (2013) 110:E1361-70. doi: 10.1073/pnas.1220723110

137. Bois PR, Borgon RA, Vonrhein C, Izard T. Structural dynamics of $\alpha$-actinin-vinculin interactions. Mol Cell Biol. (2005) 25:611222. doi: 10.1128/MCB.25.14.6112-6122.2005

138. Dewitt S, Tian W, Hallett MB. Localised PtdIns $(3,4,5)$ P3 or PtdIns $(3,4) \mathrm{P} 2$ at the phagocytic cup is required for both phagosome closure and Ca2+ signalling in HL60 neutrophils. J Cell Sci. (2006) 119:44351. doi: $10.1242 /$ jcs.02756

139. Schymeinsky J, Then C, Sindrilaru A, Gerstl R, Jakus Z, Tybulewicz VL, et al. Syk-mediated translocation of PI3K $\delta$ to the leading edge controls lamellipodium formation and migration of leukocytes. PLoS ONE. (2007) 2:e1132. doi: 10.1371/journal.pone.0001132

140. Xue, Z.-H., Feng C, Liu W-L, Tan S-M. A role of kindlin-3 in integrin $\alpha \mathrm{M} \beta 2$ outside-in signaling and the Syk-Vav1-Rac1/Cdc42 signaling axis. PLoS ONE. (2013) 8:e56911. doi: 10.1371/journal.pone.0056911

141. Wiedemann A, Patel JC, Lim J, Tsun A, van Kooyk Y, Caron E. Two distinct cytoplasmic regions of the $\beta 2$ integrin chain regulate RhoA function during phagocytosis. J Cell Biol. (2006) 172:1069-79. doi: 10.1083/jcb.200508075

142. Tzircotis G, Braga VM, Caron E. RhoG is required for both Fc $\gamma$ R-and CR3-mediated phagocytosis. J Cell Sci. (2011) 124:2897-902. doi: 10.1242/jcs.084269

143. Hall AB, Gakidis MAM, Glogauer M, Wilsbacher JL, Gao S, Swat W, et al. Requirements for Vav guanine nucleotide exchange factors and Rho GTPases in Fc $\gamma \mathrm{R}$-and complement-mediated phagocytosis. Immunity. (2006) 24:30516. doi: 10.1016/j.immuni.2006.02.005

144. Wennerberg K, Ellerbroek SM, Liu R-Y, Karnoub AE, Burridge K, Der CJ. RhoG signals in parallel with Racl and Cdc42. J Biol Chem. (2002) 277:47810-7. doi: 10.1074/jbc.M203816200

145. Prieto-Sánchez RM, Bustelo XR. Structural basis for the signaling specificity of RhoG and Racl GTPases. J Biol Chem. (2003) 278:3791625. doi: 10.1074/jbc.M301437200

146. Olazabal IM, Caron E, May RC, Schilling K, Knecht DA, Machesky LM. Rho-kinase and myosin-II control phagocytic cup formation during CR, but not Fc $\gamma \mathrm{R}$, phagocytosis. Curr Biol. (2002) 12:1413-8. doi: 10.1016/S0960-9822(02)01069-2

147. Krugmann S, Anderson K, Ridley S, Risso N, McGregor A, Coadwell J, et al. Identification of ARAP3, a novel PI3K effector regulating both Arf and Rho GTPases, by selective capture on phosphoinositide affinity matrices. Mol Cell. (2002) 9:95-108. doi: 10.1016/S1097-2765(02)00434-3

148. Palazzo AF, Cook TA, Alberts AS, Gundersen GG. mDia mediates Rhoregulated formation and orientation of stable microtubules. Nat Cell Biol. (2001) 3:723. doi: 10.1038/35087035

149. Albert ML, Kim J-I, Birge RB. $\alpha$ v $\beta 5$ integrin recruits the CrkII-Dock180Rac1 complex for phagocytosis of apoptotic cells. Nat Cell Biol. (2000) 2:899-905. doi: 10.1038/35046549
150. Gumienny TL, Brugnera E, Tosello-Trampont A-C, Kinchen JM, Haney LB, Nishiwaki K, et al. CED-12/ELMO, a novel member of the CrkII/Dock180/Rac pathway, is required for phagocytosis and cell migration. Cell. (2001) 107:27-41. doi: 10.1016/S0092-8674(01)00520-7

151. Wu Y, Singh S, Georgescu M-M, Birge RB. A role for Mer tyrosine kinase in $\alpha v \beta 5$ integrin-mediated phagocytosis of apoptotic cells. J Cell Sci. (2005) 118:539-53. doi: 10.1242/jcs.01632

152. Sanjay A, Houghton A, Neff L, DiDomenico E, Bardelay C, Antoine E, et al. $\mathrm{Cbl}$ associates with Pyk2 and Src to regulate Src kinase activity, $\alpha \mathrm{v} \beta 3$ integrin-mediated signaling, cell adhesion, osteoclast motility. J Cell Biol. (2001) 152:181-96. doi: 10.1083/jcb.152.1.181

153. Miyazaki T, Sanjay A, Neff L, Tanaka S, Horne WC, Baron R. Src kinase activity is essential for osteoclast function. J Biol Chem. (2004) 279:176606. doi: 10.1074/jbc.M311032200

154. Nakaya M, Tanaka M, Okabe Y, Hanayama R, Nagata S. Opposite effects of rho family GTPases on engulfment of apoptotic cells by macrophages. J Biol Chem. (2006) 281:8836-42. doi: 10.1074/jbc.M510972200

155. DeBakker CD, Haney LB, Kinchen JM, Grimsley C, Lu M, Klingele D, et al. Phagocytosis of apoptotic cells is regulated by a UNC-73/TRIO-MIG2/RhoG signaling module and armadillo repeats of CED-12/ELMO. Curr Biol. (2004) 14:2208-16. doi: 10.1016/j.cub.2004.12.029

156. Tosello-Trampont, A.-C., Nakada-Tsukui K, Ravichandran KS. Engulfment of apoptotic cells is negatively regulated by Rho-mediated signaling. J Biol Chem. (2003) 278:49911-9. doi: 10.1074/jbc.M306 079200

157. Leverrier Y, Ridley AJ. Requirement for Rho GTPases and PI 3-kinases during apoptotic cell phagocytosis by macrophages. Curr Biol. (2001) 11:195-9. doi: 10.1016/S0960-9822(01)00047-1

158. Leverrier Y, Lorenzi R, Blundell MP, Brickell P, Kinnon C, Ridley AJ, et al. Cutting edge: the Wiskott-Aldrich syndrome protein is required for efficient phagocytosis of apoptotic cells. J Immunol. (2001) 166:48314. doi: 10.4049/jimmunol.166.8.4831

159. Mao Y, Finnemann SC. Essential diurnal Racl activation during retinal phagocytosis requires $\alpha \mathrm{v} \beta 5$ integrin but not tyrosine kinases focal adhesion kinase or Mer tyrosine kinase. Mol Biol Cell. (2012) 23:110414. doi: 10.1091/mbc.e11-10-0840

160. MacDonald JM, Beach MG, Porpiglia E, Sheehan AE, Watts RJ, Freeman MR. The Drosophila cell corpse engulfment receptor Draper mediates glial clearance of severed axons. Neuron. (2006) 50:86981. doi: 10.1016/j.neuron.2006.04.028

161. Ziegenfuss JS, Biswas R, Avery MA, Hong K, Sheehan AE, Yeung Y-G, et al. Draper-dependent glial phagocytic activity is mediated by Src and Syk family kinase signalling. Nature. (2008) 453:935-9. doi: 10.1038/nature06901

162. Bajic G, Yatime L, Sim RB, Vorup-Jensen T, Andersen GR. Structural insight on the recognition of surface-bound opsonins by the integrin I domain of complement receptor 3. Proc Natl Acad Sci USA. (2013) 110:1642631. doi: $10.1073 /$ pnas. 1311261110

163. Phan TG, Grigorova I, Okada T, Cyster JG. Subcapsular encounter and complement-dependent transport of immune complexes by lymph node B cells. Nat Immunol. (2007) 8:992-1000. doi: 10.1038/ni1494

164. Gray EE, Cyster JG. Lymph node macrophages. J Innate Immun. (2012) 4:424-36. doi: 10.1159/000337007

165. Gonzalez SF, Degn SE, Pitcher LA, Woodruff M, Heesters BA, Carroll MC. Trafficking of B cell antigen in lymph nodes. Ann Rev Immunol. (2011) 29:215-33. doi: 10.1146/annurev-immunol-031210-101255

166. Bachmann MF, Jennings GT. Vaccine delivery: a matter of size, geometry, kinetics and molecular patterns. Nat Rev Immunol. (2010) 10:78796. doi: $10.1038 /$ nri2868

Conflict of Interest: The authors declare that the research was conducted in the absence of any commercial or financial relationships that could be construed as a potential conflict of interest.

Copyright (C) 2020 Torres-Gomez, Cabañas and Lafuente. This is an open-access article distributed under the terms of the Creative Commons Attribution License (CC $B Y)$. The use, distribution or reproduction in other forums is permitted, provided the original author(s) and the copyright owner(s) are credited and that the original publication in this journal is cited, in accordance with accepted academic practice. No use, distribution or reproduction is permitted which does not comply with these terms. 